Acta vet. scand. $1981,22,180-188$.

From the Division of Pathology, Indian Veterinary Research Institute, Izatnagar, India, and the Department of Pathology, Faculty of Veterinary Medicine, Swedish University of Agricultural Sciences, Uppsala, Sweden.

\title{
ULTRASTRUCTURAL STUDIES OF PARATUBERCULOSIS (JOHNE'S DISEASE) IN GOATS
}

\author{
By \\ O. P. Paliwal and C. Rehbinder
}

\begin{abstract}
PALIWAL, O. P. and C. REHBINDER: Ultrastructural studies of paratuberculosis (Johne's disease) in goats. Acta vet. scand. 1981, 22, $180-188$. - Biopsy material of the ileum and corresponding mesenteric lymph nodes from 10 naturally infected goats was studied. In ileum a lass of epithelial cells and infiltration of epitheloid cells, macrophages and a low number of lymphocytes, plasma cells and occasional eosinophils were seen. Ultrastructurally, the epithelial cells showed degenerative changes. Epitheloid cells were characterized by a large nucleus and a wide cytoplasm rich in free ribosomes.

Macrophages had been fixed in the process of engulfing bacteria or contained bacteria in phagosomes and phagolysosomes. Large phagolysosomes were common. In macrophages with many or large phagolysosomes, few or no lysosomes were observed. Degenerative changes were seen in macrophages containing many bacteria. Degenerative changes of capillary endothelium were observed. The intercellular spaces were distended by oedema and contained cell debris.

The mesenteric lymph nodes were infiltrated with epitheloid cells and macrophages. The ultrastructural picture of these cells was almost identical to that of the ileum.

The differences between the changes found in naturally infected and experimentally infected animals are discussed. It is concluded that the mode of infection, the number of bacteria to which the animal is exposed and the intervals between events of exposure may play a role.
\end{abstract}

paratuberculosis; goat; ultrastructure.

There are only few reports on the ultrastructure of Johne's disease (Smith 1969, Majeed 1972, Kim et al. 1976) and only one concerning goats (Majeed). In some respects the results of these reports are inconsistent. The aim of the present study was to investigate the ultrastructural morphogenesis of lesions and hostparasite interaction in naturally infected Indian goats. 


\section{MATERIAL AND METHODS}

Biopsy material was collected from 10 goats (Table 1), belonging to a herd positive for Johne's disease. The animals were kept on concentrates, green fodder and water ad libitum.

Biopsied animals were selected according to clinical signs and by examination of faecal samples for morphologically typical paratuberculosis acid fast bacteria, and indirect immunofluorescent test on serum samples. After biopsies were taken, the diagnosis was confirmed by gross and histopathological examination of the carcass of each experimental animal.

T a b l e 1. Clinical status of biopsied goats.

\begin{tabular}{|c|c|c|c|c|}
\hline Goat No. & Breed & Age (yrs.) & Sex & Clinical signs \\
\hline 1 & BB & 1 & $\mathbf{F}$ & + \\
\hline 2 & B & 2 & $\mathbf{M}$ & $+t+$ \\
\hline 3 & BxBB & 2.5 & $\mathbf{F}$ & $+t+$ \\
\hline 4 & $\mathrm{BB}$ & 2.5 & $\mathbf{F}$ & $+t$ \\
\hline 5 & BB & 2.5 & $\mathbf{F}$ & + \\
\hline 6 & B & 2.5 & $\mathbf{F}$ & $++t$ \\
\hline 7 & B & 3 & $\mathbf{M}$ & $++t$ \\
\hline 8 & BB & 4 & $\mathbf{F}$ & $+t+$ \\
\hline 9 & BB & 4.5 & $\mathbf{M}$ & $+t+$ \\
\hline 10 & BB & 6.5 & $\mathbf{F}$ & $+t+$ \\
\hline \multicolumn{2}{|c|}{$\begin{array}{l}\text { - Barbari } \\
\text { - Black Bengal } \\
\text { - Cross Barbari- } \\
\text { Black Bengal }\end{array}$} & \multicolumn{3}{|c|}{$\begin{aligned} &+ \text { Weak with loose faeces } \\
&+ \text { Weak with occasional diarrhoea } \\
&++ \text { Progressive and intermittent } \\
& \text { diarrhoea }\end{aligned}$} \\
\hline
\end{tabular}

Biopsies, about $1 \mathrm{~mm}$ thick, were obtained surgically under local anaesthesia from ileum about $10 \mathrm{~cm}$ from the ileocaecal valve and from the corresponding mesenteric lymph nodes. They were washed directly with cold saline and fixed for $3 \mathrm{~h}$ in $3 \%$ glutaraldehyde, buffered with $0.1 \mathrm{~mol} / \mathrm{l}$ sodium cacodylate, $\mathrm{pH}$ 7.4 at $4^{\circ} \mathrm{C}$. After fixation, the material was washed twice for 5 min with sodium cacodylate buffer at $4^{\circ} \mathrm{C}$ and post-fixed in buffered $1 \%$ osmium tetraoxide solution, $\mathrm{pH} 7.4$ for $2 \mathrm{~h}$ at $4^{\circ} \mathrm{C}$.

After embedding in Araldite (Ladd Research Industries Inc., USA), $1 \mu \mathrm{m}$ thick sections were cut and stained with toludine blue for light microscopy. Ultrathin sections were cut and placed on uncoated copper grids, stained with uranyl acetate and examined in a Philips electron microscope at $30-60 \mathrm{kV}$ and magnification between 1,500 and 30,000 times. 


\section{RESULTS}

At necropsy, macroscopical lesions were confined to the intestine and the mesenteric lymph nodes. The histological picture of the ileum showed a loss of most of the epithelial cells. The lamina propria and submucosa were markedly infiltrated by epitheloid cells, macrophages and, in addition, a low number of diffusely distributed lymphocytes, plasma cells and also occasional eosinophils. Giant cells were not found.

On EM examination, the epithelial cells appeared swollen with a dilated and often vesiculated endoplasmic reticulum. Most of the mitochondria showed a matrix of increased electron density or were swollen with disorganized or indistinct cristae. In some epithelial cells, the nuclei showed chromatin condensation.

The epitheloid cells were characterized by a large, usually centrally, situated nucleus. The cytoplasm was rich in ribosomes, and larger than the nucleus. Most epitheloid cells had a moderate number of mitochondria and a low amount of endoplasmic reticulum (Fig. 1), but in some cells a somewhat increased number of these organelles were found. In the epitheloid cells, bacilli were never found.

The ultrastructure of the macrophages showed bacteria in the process of being phagocytized (Figs. 2 and 10) and bacteria in phagosomes (Figs. 3, 4 and 6) and phagolysosomes (Figs. 2, 5, 6 and 7). Phagosomes contained morphologically intact (Fig. 3) and occasional dividing bacteria. Phagolysosomes contained morphologically intact, occasional dividing (Fig. 4) and lysed bacteria (Fig. 5). Phagolysosomes with dividing bacteria contained very little lysosomal material (Fig. 4). Fusion of phagosomes and lysosomes, forming phagolysosomes and lysosomes fusing with phagolysosomes was commonly observed (Fig. 2). By fusion very large phagolysosomes were formed (Figs. 6 and 7). Lysed bacteria with a laminated, myelin-like appearance were seen in some phagolysosomes (Fig. 8). In cells with many or large phagolysosomes, the number of lysosomes appeared to be very low or nil.

In the macrophages an increase of alterations of the organelles was also noted in correlation with the number of bacteria in phagosomes and phagolysosomes. In cells containing several or numerous bacteria, in several or large phagolysosomes, the golgi apparatus and the endoplasmic reticulum was dilated and vesiculated, containing a slightly flocculent material of low electron 
density (Fig. 2). The rough endoplasmic reticulum was to a large extent degranulated. The mitochondria showed an increased electron density of the matrix or were swollen with disorganization or loss of cristae (Figs. 7 and 9). Correlated with the organelle changes was an intracellular oedema, characterized by clefts containing a flocculent material of low electron density, and ribosomes detached from the endoplasmic reticulum (Fig. 2).

The intercellular spaces were distended by oedema and contained membrane coated cisternae, cytoplasmic fragments and cell debris (Figs. 9 and 10). Among the cytoplasmic fragments, phagosomes and phagolysosomes still containing bacteria could be seen (Fig. 9). A free dividing bacterium was found in the intercellular space (Fig. 10). Collagen fibres were observed in the intercellular spaces of the lamina propria (Fig. 9).

In capillaries, degenerative changes were observed in the endothelial cells, characterized by intracellular oedema, swollen mitochondria with destroyed cristae and degranulated dilated rough endoplasmic reticulum (Fig. 11).

In the mesenteric lymph nodes, histologically, the cortical sinuses were infiltrated with epitheloid cells and macrophages. In some instances the lymphoid follicles were also infiltrated. The ultrastructural picture of the epitheloid cells and macrophages in the lymph nodes was almost identical to that of the ileum. Collagen fibres in the intercellular spaces, however, were not observed.

\section{DISCUSSION}

Most epithelial cells were missing and remaining cells showed degenerative changes as was previously reported by Kim et al. (1976). No bacilli were found in epithelial cells. These degenerative changes are suggested by Merkal et al. (1970) to be due to a delayed hypersensitivity reaction producing a release of cytotoxin. It seems likely that a release of cytotoxin also affects the endothelial cells of capillaries, the degeneration of the epithelial cells being enhanced by an improper nutrition.

Epitheloid cells did not contain any bacilli and appeared to be without degenerative changes. There were indications of increased activity in some cells but the distinct differences reported by Majeed (1972) were not present.

In macrophages, phagosomes contained morphologically intact and occasional dividing bacteria while phagolysosomes contained both morphologically intact and lysed bacteria. 
The formation of phagolysosomes corresponds with earlier reports concerning Mycobacterium Johnei (Majeed), M. tuberculosis (Dumont \& Sheldon 1965, Armstrong \& D'Arcy Hart 1971), M. lepraemurium (Chang et al. 1967, Brown \& Draper 1970, D'Arcy Hart et al. 1972) and Listeria monocytogenes (Leake et al. 1971). The presence of multilamellar, myelin-like structures around damaged bacilli was also earlier reported (Leake \& Myrvik 1966, D'Arcy Hart et al., Majeed).

There is only one earlier report on the ultrastructure of Johne's disease (Kim et al. 1976) caused by natural infection and in that report, similar to the findings in our investigation, two types of macrophages as reported by Majeed were not found. This difference and also the somewhat different appearance of the epitheloid cells may be due to differences in breed susceptibility or to the mode of infection.

In phagosomes morphologically intact and occasional dividing bacteria were found similar to the findings by Majeed. Occasional dividing bacteria were also found in phagolysosomes but these phagolysosomes contained very little lysosomal material. In addition, several intact bacteria and also one dividing bacterium were found in the intracellular spaces. It is possible that the dividing bacterium had escaped from a degenerated and ruptured cell, and thus started its division inside a phagosome, but extracellular division can not be excluded.

Several factors may be of importance for the development of the disease, either towards recovery or towards progression.

It is apparent that macrophages can destroy M. paratuberculosis bacteria, but also that these bacteria during certain circumstances may multiply and spread.

A correlation between the number of bacteria administered and the occurrence of clinically manifest disease, and also a correlation between the size of the dose and the severity of the disease has been experimentally shown. In the same experiments it was also shown that animals infected with a low number of bacteria did recover (Brotherstone et al. 1961, Kluge et al. 1968). It has also been reported that when few organisms were phagocytized, acid fast remnants in phagocytic vacuoles with high acid phosphatase activity indicated disintegration of the bacteria, while when many bacteria were ingested, the acid phosphatase activity was lost and the organisms multiplied uninhibited by lysosomal activity (Merkal et al. 1968). 
O. P. Paliwal and C. Rehbinder: Ultrastructural Studies of Tuberculosis (Johnes Disease) in Goats.

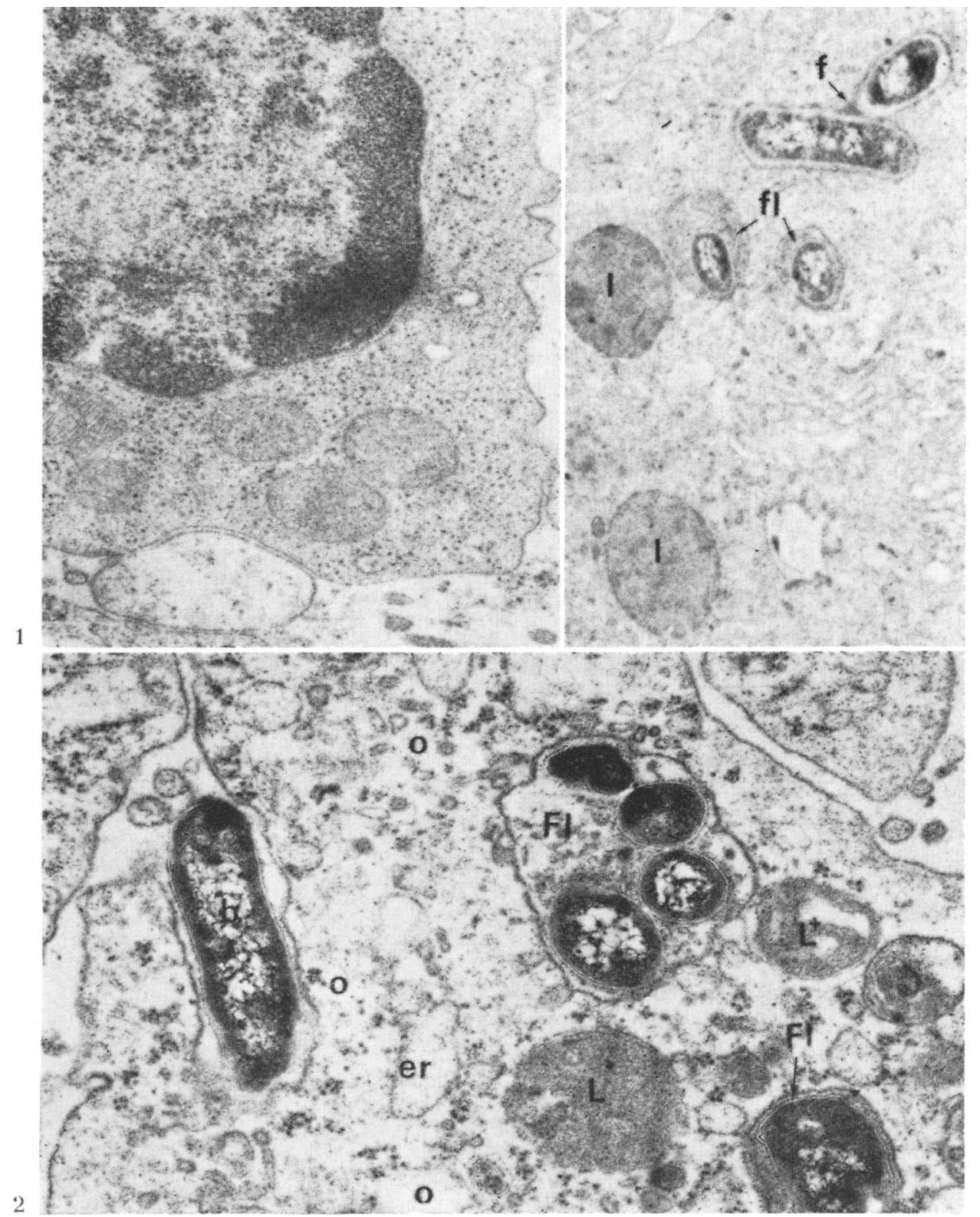

F i g u re 1. Epitheloid cell. Note the finely granulated cytoplasm, rich in ribosomes. Mesenteric lymph node $\times 19,500$.

Figure 2. Macrophage. Bacterium being engulfed (b). Phagolysosomes containing bacteria (FI), lysosomes (L) degranulated endoplasma reticulum (er) and intracellular oedema (o). Note lysosomes in contact with phagolysosome. Ileum $\times 39,500$.

F i g u r e 3. Macrophage. Note lysosomes (l), phagolysosomes (fl) and fusion of two phagosomes. Ileum $\times 19,500$. 


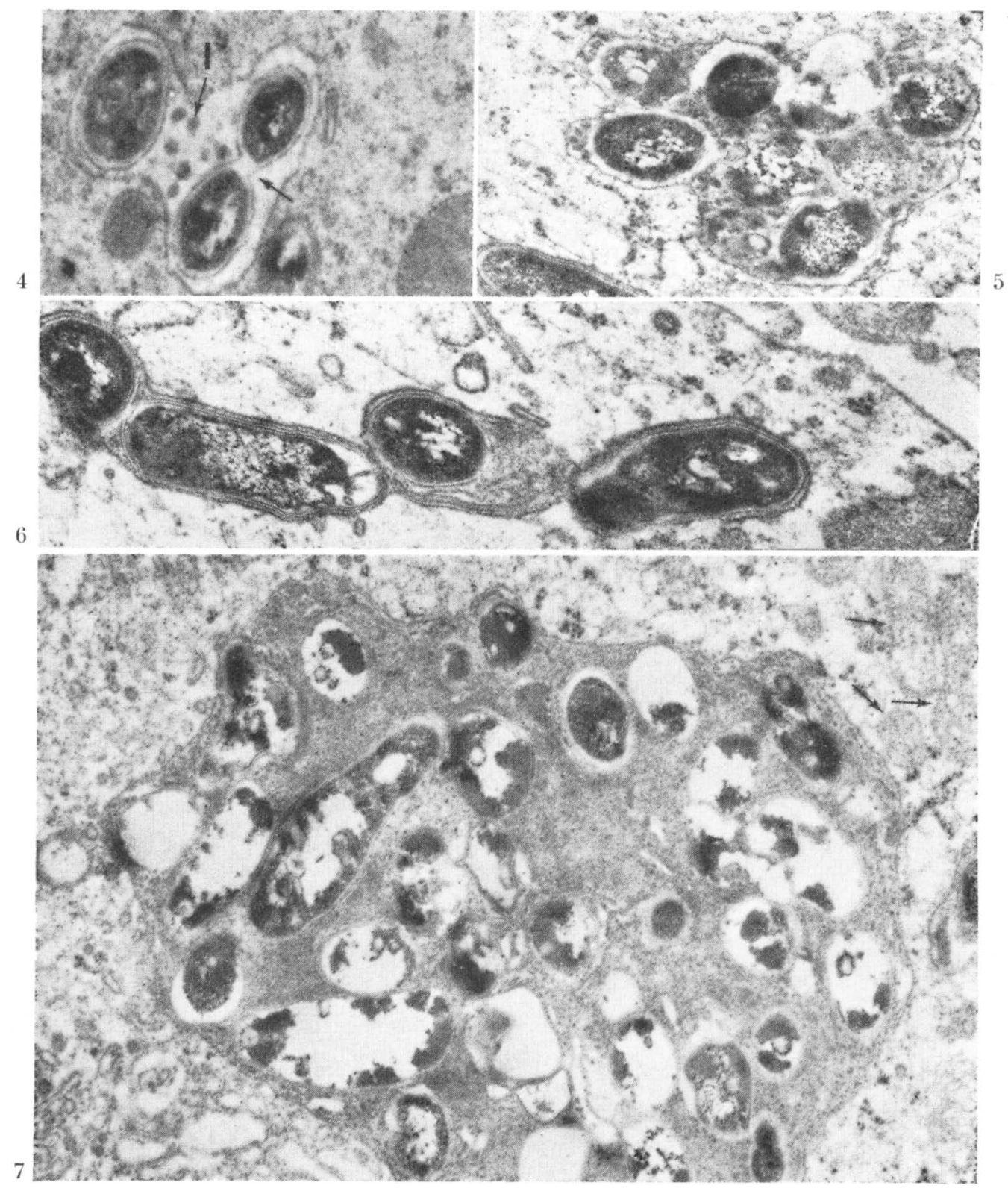

F i g u re 4. Dividing bacteria in phagolysosome. Note common cell membrane $(\rightarrow)$ and lysosomal material $(l \rightarrow)$. Ileum $\times 39,000$.

$\mathrm{F}$ ig u re 5. Phagosome containing intact and lysed bacteria. Ileum $\times 29,250$.

$\mathrm{F}$ ig u r e 6. Fusion of phagosomes and phagolysosomes. Ileum $\times$ 39,000 .

Fig u re 7. Very large phagolysosome. Note mitochondria with increased electron density and disorganized cristae $(\rightarrow)$. Mesenteric lymph node $\times 29,250$. 


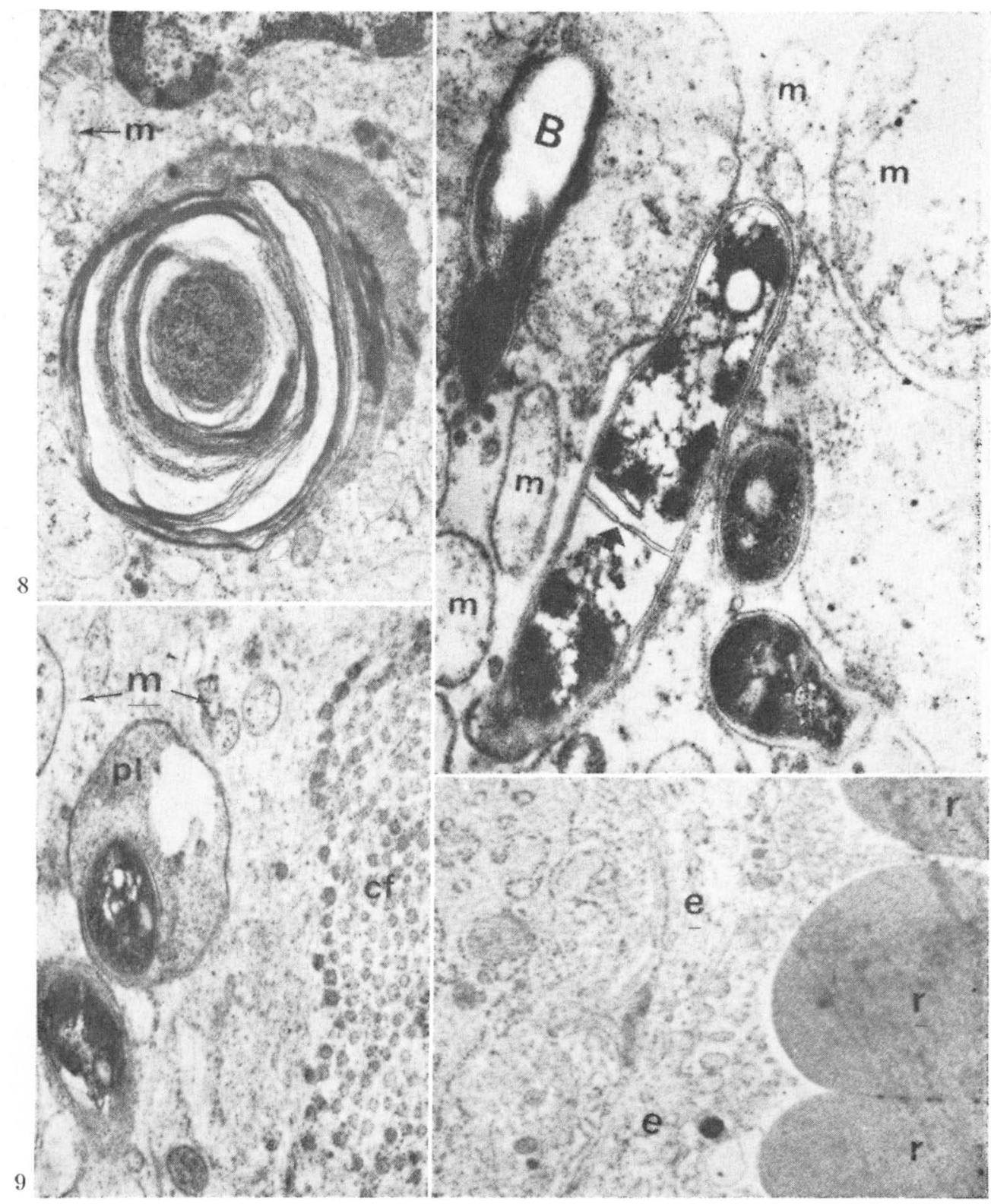

Figure 8. Lysed bacterium in phagolysosome with a laminated myelin-like appearance. Note swollen mitochondrium $(\mathrm{m} \rightarrow)$ with disorganized cristae. Mesenteric lymph node $\times 29,250$.

Figure 9. Cell debris in intercellular space. Note free phagolysosome with bacterium $(\mathrm{pl})$, membrane coated cisternae $(\mathrm{m})$, collagen fibres $(\mathrm{cf})$. Ileum $\times 39,000$.

Figure 10 . Bacterium dividing in intercellular space $(\rightarrow)$. To the left one bacterium being engulfed (B). Note membrane coated cisternae $(\mathrm{m})$. Ileum $\times 29,250$.

Fig u re 11. Capillary with red blood corpuscles ( $r)$. Note degenerative changes in the endothelium (e) and marked intracellular oedema. Ileum $\times 13,650$. 
The suggestion by Brown et al. (1969) that the lysosomal enzymes would provide nutrients for the growth of mycobacteria seems less likely. Instead, the delay in the destruction of bacteria could be due to paucity or an inadequate production of lysosomes which in its turn may imply that a considerable amount of lysosomal material may be needed to destroy the capsule of the bacteria. The production of lysosomes may thus not be enough to kill all bacteria of a heavy infection dose.

The duration of the disease has to be considered as for the production of lesions and cellular response. In a chronic stage the replication of bacteria may be considerable resulting in an inadequate production of lysosomal material. In addition, macrophages will degenerate which may partly be due to release of cytotoxin (Merkal et al. 1970).

Our observation of dividing bacteria in phagosomes, also found by Majeed, and in phagolysosomes containing small amounts of lysosomal material indicates that lack of lysosomal material will give the bacteria opportunity to multiply which is in accordance with the finding by Merkal et al. (1968).

The finding of intact bacilli in phagosomes and phagolysosomes may simply indicate that a time factor is involved. It is thus possible that a bacillus that has been recently phagocytized at the moment when the cell was exposed to the fixative still appears intact but would later have undergone lysis.

A peri-bacillary space has been reported in connection with experimental infection of M. Johnei (Majeed), M. tuberculosis (Dumont \& Sheldon, Armstrong \& D'Arcy Hart) and M. lepraemurium (Allen et al. 1965). The material in the peri-bacillary space has, concerning $M$. lepraemurium, been found to be parallel thin fibrils with an appearance like that of wax $D_{s}$ isolated from cell walls of mycobacteria (Draper \& Rees 1970).

It has been suggested that the fibrils are an inert and mechanically protective material that may explain the resistance of mycobacterial pathogens to killing by phagocytic cells (Draper \& Rees).

In our investigation and in the investigation by Kim et al. this finding was not present, nor in a study of $M$. smegmatis (Leake \& Myrvik). In an investigation of murine leprosy by Allen et al. (1965), little or no peribacillary space was observed around engulfed bacteria $2-4$ weeks after infection, while during later intervals, up to 5 months, a distinct peri-bacillary space was evident. 
The absence of a peri-bacillary space may indicate that macrophages are competent to degrade and lyse bacilli while the presence of a peri-bacillary space thus indicates that the production of lysosomal material is insufficient to dissolve the capsule of the bacterium. This will be seen in experiments using a heavy infection dose or in a later stage of disease when replication has been considerable. The peri-bacillary spaces may consequently instead occur as a sign of insufficient "killing ability" of the macrophages by inadequate production of lysosomal material. Another hypothesis might be that the microorganism is able to produce a substance that inhibits the formation of lysosomes.

Our finding of a low number or absence of lysosomes in macrophages with large or many phagolysosomes supports the importance of the production of lysosomal material. It also gives an indication of the importance of the number of bacteria to which the animal is exposed and the mode of infection.

Natural infection usually represents small and repeated doses while experimental infections usually represent large doses administrated at intervals.

This may be the reason for the different pictures present in experimentally infected animals (Smith 1969, Majeed) and naturally infected animals as seen in this study and by Kim et al.

The damage of at first hand epithelial cells and macrophages resembled the finding by Kim et al. but differed from the studies of Smith and Majeed. It is notable that in naturally infected cases, the cellular damage was considerable with organelle fragments in the intracellular spaces while in experimental animals this was not found. This may also be an indication of the role played by the mode of infection.

The degeneration and destruction of macrophages in which bacteria have multiplied may be part of the slow spread of bacteria. It is possible that the intercellular oedema and cell detritus may furnish the nutrition needed for the growth of the organisms as suggested by Kim et al. It is also possible that bacteria may multiply not only intracellularly but also extracellularly as indicated by the finding of a dividing bacterium in the intercellular space. It seems likely that experimental infections may produce a somewhat different tissue response from natural infections. The mode of infection, number of bacteria to which the animals are exposed and the intervals between events of exposure may thus play a role. 
In our investigation we found collagen fibres in the intercellular spaces in the lamina propriae. A similar finding, but much more extensive is reported in Johne's disease in a bovine (Kim et al.). It is possible that the collagen fibres represent a reparative process and that the mentioned differences are due to different stages of disease, but a species difference can not be excluded.

\section{ACKNOWLEDGEMENT}

The skillful technical assistance of Marianne Ekwall and Bengt Ekberg is gnatefully acknowledged.

\section{REFERENCES}

Allen, J. M., E. M. Brieger \& R. J. W. Rees: Electron micrascopy of the host-cell parasite relation in murine leprosy. J. Path. Bact. 1965, 89, 301-306.

D'Arcy Hart, P., J. A. Armstrong, C. A. Brown \& P. Draper: Ultrastructural study of the behaviour of macrophages toward parasitic mycobacteria. Infect. Immun. 1972, 5, 803-807.

Armstrong, J. A. \& P. D'Arcy Hart: Response of cultured macrophages to Mycobacterium tuberculosis with observations of fusion of lysasome with phagosomes. J. exp. Med. 1971, 134, 713-740.

Brotherstone, J. G., N. J. L. Gilmour \& J. McA. Samuel: Quantitative studies of Mycobacterium Johnei in the tissues of sheep. J. comp. Path. 1961, 71, 286-.299.

Brown, C. A., P. Draper \& P. D'Arcy Hart: Mycobacteria and lysosomes: a paradox. Nature (Lond.) 1969, 221, 658-660.

Brown, C. A. \& P. Draper: An electron microscope study of rat fibroblasts infected with Mycobacterium lepraemurium. J. Path. 1970, 102, 21-26.

Chang, Y, T., R. N. Andersen \& Z. Vaituzis: Growth of Mycobacterium lepraemurium in cultures of mouse peritoneal macrophages. J. Bact. 1967, 93, 1119-1131.

Draper, P. \& R. J. W. Rees: Electron transparent zone of Mycobacteria may be a defence mechanism. Nature (Lond.) $1970,228,860-$ 861.

Dumont, A. \& H. Sheldon: Changes in the fine structure of macrophages in experimentally produced tuberculous granulomas in hamsters. Lab. Invest. 1965, 14, 2034-2055.

Kim, J. C. S., V. L. Sanger \& D. L. Whitenack: Ultrastructural studies of bovine paratuberculosis (Johne's disease). Vet. Med./Small Anim. Clin. 1976, 71, Jan., 78-83.

Kluge, J. P., R. S. Merkal, W. S. Monlux, A. B. Larsen, K. E. Kopecky, F. K. Ramsey \& R. P. Lehmann: Experimental paratuberculosis in sheep after oral, intratracheal or intravenous inoculation: Lesions and demonstration of etiologic agent. Amer. J. vet. Res. 1968, 29, 953-962. 
Leake, E. S. \& Q. N. Myrvik: Digestive vacuole formation in alveolar macrophages after phagocytosis of Mycobacterium smegmatis in vivo. J. reticuloendoth. Soc. 1966, 3, 83-100.

Leake, E. S., D. G. Evans \& Q. N. Myrvik: Ultrastructural patterns of bacterial breakdown in normal and granulomatous rabbit alveolar macrophages. J. reticuloendoth. Soc. 1971, 9, 174-199.

Majeed, S. K.: The Paratuberculous Inflammatory Process in Goats. Ph.D. thesis, Univ. of Utrecht, 1972, pp. 104-121.

Merkal, R. S., J. P. Kluge, W. S. Monlux, A. B. Larsen, K. E. Kopecky, L. Y. Quinn \& R. P. Lehmann: Experimental paratuberculosis in sheep after oral, intratracheal or intravenous inoculation: Histochemical localization of hydrolas activities. Amer. J. vet Res. 1968, 29, 985-994.

Merkal, R. S., K. E. Kopecky, A. B. Larsen \& R. D. Ness: Immunologic mechanisms in bovine paratuberculosis. Amer. J. vet. Res. 1970, $31,475-485$.

Smith, K.: Electron microscopical observations of Mycobacterium Johnei. Res. Vet. Sci. 1969, 10, 1-3.

\section{SAMMANFATTNING}

Ultrastrukturella studier av paratuberkulos (Johne's sjukdom) hos get.

Biopsier från ileum och korresponderande mesenteriallymfknutor uttagna från 10 naturligt infekterade getter har studerats. I ileum förelåg förlust av epitelceller och infiltration av epiteloida celler, makrofager, ett mindre antal lymfocyter, plasmaceller och enstaka eosinofiler. Ultrastrukturellt uppvisade epitelcellerna degenerativa förändringar. Epiteloida celler karakteriserades av en stor kärna och en voluminös cytoplasma rik på fria ribosomer.

Makrofagerna upptog bakterier och bakterier förelåg intracellulärt i fagosomer och fagolysosomer. Bildandet av stora fagolysosomer var ett vanligt fynd. I makrofager med många eller stora fagolysosomer förelåg få eller inga lysosomer. Degenerativa förändringar var påtagliga i makrofager innehållande rikligt med bakterier. Degenerativa förändringar $i$ kapillärendotel iakttogs. Intercellularrummen var dilaterade av ödem innehållande celldebris. I lamina propria förelåg $\mathrm{i}$ intercellularrummen även kollagena fibrer.

Histologiskt uppvisade mesenteriallymfknutorna infiltrat av epiteloida celler och makrofager. Ultrastrukturen hos dessa celler var nästan identisk med de som förekom i ileum.

De skillnader som föreligger mellan bilden av naturligt och experimentellt infekterade djur diskuteras. Resultaten av undersökningen pekar på att infektionssätt, antal bakterier djuret exponeras för och intervaller mellan infektionstillfällen torde vara av betydelse.

(Received December 20, 1980).

Reprints may be requested from: C. Rehbinder, the Department of Pathology, Faculty of Veterinary Medicine, Swedish University of Agricultural Sciences, S-750 07 Uppsala, Sweden. 